\title{
Detection of an untyped strain of bovine respiratory syncytial virus in a dairy herd
}

\section{Detecção de uma estirpe não tipável do vírus respiratório sincicial bovino em rebanho leiteiro}

\author{
Ingrid Bortolin Affonso ${ }^{1}$; Andressa de Souza ${ }^{2}$; Matheus Cavalheiro Martini ${ }^{3}$; \\ Márcia Mercês Aparecida Bianchi dos Santos"; Fernando Rosado Spilki \\ Clarice Weis Arns ${ }^{6}$; Samir Issa Samara ${ }^{7 *}$
}

\begin{abstract}
Bovine respiratory syncytial virus (BRSV) causes important lower respiratory tract illness in calves. According to $\mathrm{F}$ and $\mathrm{G}$ proteins genetic sequences, three BRSV subgroups have been reported and characterized in several countries, showing differences in its distribution. In Brazil, the virus is widely disseminated throughout the herds and the few characterized isolates revealed the solely occurrence of the subgroup B. This study describes the detection and characterization of an untyped BRSV strain from a twenty-days-old calf from a herd without clinical respiratory disease. Nasal swabs were analyzed by RT-nested PCR for the F and G proteins genes. One sample has amplified the F protein gene. Sequencing and subsequent phylogenetic reconstruction were accomplished, revealing that the strain could not be grouped with any other BRSV subgroups reported. This result may suggest that the BRSV is in constantly evolution, even in Brazil, where the vaccination is not a common practice. More detailed studies about BRSV characterization are necessary to know the virus subgroups distribution among the Brazilian herds to recommend appropriated immunoprophylaxis.
\end{abstract}

Key words: BRSV, F protein gene, RT-nested PCR, sequences, subgroup

\section{Resumo}

O vírus respiratório sincicial bovino (BRSV) é responsável por causar severa doença respiratória principalmente em bezerros. De acordo com sequências genéticas das proteínas $\mathrm{F}$ e $\mathrm{G}$ deste vírus, três subgrupos de BRSV foram relatados e caracterizados em vários países, mostrando diferenças nas suas distribuições. No Brasil, o vírus encontra-se disseminado pelos rebanhos bovinos e, dos poucos

\footnotetext{
${ }^{1}$ Discente do Programa de Pós-graduação em Medicina Veterinária, Dept ${ }^{\circ}$ de Medicina Veterinária Preventiva e Reprodução Animal, Universidade Estadual Paulista UNESP, Faculdade de Ciências Agrárias e Veterinárias, Jaboticabal, SP, Brasil. E-mail: ibaffonso@gmail.com

${ }^{2}$ Discente, Dept ${ }^{\mathrm{o}}$ de Medicina Veterinária Preventiva e Reprodução Animal, UNESP, Jaboticabal, SP, Brasil. E-mail: andressa_ unesp@yahoo.com.br

${ }^{3}$ Discente, Instituto de Biologia, Universidade Estadual de Campinas, UNICAMP, Campinas, SP, Brasil. E-mail: crmv2007@, hotmail.com

${ }^{4}$ Prof $^{\mathrm{a}}$ Adjunta, Dept ${ }^{\mathrm{o}}$ de Parasitologia, Microbiologia e Imunologia, Universidade Federal de Juiz de Fora, UFJF, Juiz de Fora, MG, Brasil. E-mail: marcia.bianchi@ufjf.edu.br

${ }^{5}$ Prof. Titular, Universidade FEEVALE, FEEVALE, Novo Hamburgo, RS, Brasil. E-mail: fernandors@feevale.br

${ }^{6}$ Prof ${ }^{\mathrm{a}}$ Titular, Instituto de Biologia, Universidade Estadual de Campinas, UNICAMP, Campinas, SP, Brasil. E-mail: arns@, unicamp.br

${ }^{7}$ Prof. Titular, Dept ${ }^{\circ}$ de Medicina Veterinária Preventiva e Reprodução Animal, UNESP, Jaboticabal, SP, Brasil. E-mail: samara@ fcav.unesp.br

* Author for correspondence
} 
isolados caracterizados, todos foram classificados no subgrupo B. Assim, o estudo descreve a detecção e caracterização de uma estirpe de BRSV não tipável proveniente de um bezerro de vinte dias de idade, de um rebanho sem histórico clínico de doença respiratória. Suabes nasais foram analisados pela técnica de RT-nested PCR para os genes das proteínas F e G do BRSV e uma amostra amplificou o gene da proteína $\mathrm{F}$. O sequenciamento da amostra e subsequente reconstrução filogenética mostrou o não agrupamento da estirpe com quaisquer outros subgrupos de BRSV relatados. Este resultado sugere a constante evolução do BRSV, mesmo no Brasil, onde a vacinação não é uma prática comum. Estudos mais detalhados sobre a caracterização do BRSV são necessários para melhor entender a distribuição dos subgrupos nos rebanhos brasileiros a fim de proporcionar medidas de imunoprofilaxia adequadas.

Palavras-chave: BRSV, Gene da proteína F, RT-nested PCR, sequências, subgrupo

\section{Introduction}

The bovine respiratory syncytial virus (BRSV) is an economically significant pathogen of cattle production (BAKER; FREY, 1985). A member of the Paramyxoviridae family (order Mononegavirales), subfamily Paramyxovirinae, genus Pneumovirus (BUNT et al., 2005), this virus is one of the most important causes of lower respiratory tract infections in calves (LARSEN, 2000).

The BRSV viral envelope glycoproteins play an important role in infectivity, viral replication and immune response (FURZE et al., 1994). The G protein mediates the attachment of the virus to host cells, and the fusion protein $(\mathrm{F})$ is responsible for virus penetration through fusion between the viral and host cell membranes, resulting in multinucleated giant cells (VALARCHER; TAYLOR, 2007). The F protein also constitutes the main target of the host immune system (TAYLOR et al., 1992; TAYLOR et al., 1997; THOMAS et al., 1998). Probably the BRSV evolution varies according to the gene, being the $G$ protein gene highly tolerant to fixation of mutations when compared to F (VALARCHER; SCHELCHER; BOURHY, 2000). Therefore, most studies concerning characterization of isolates were focused on this protein (PROZZI et al., 1997; SCHRIJVER et al., 1998; SPILKI et al., 2006; BIDOKHTI et al., 2012). Even though, progressive accumulation of nucleotide changes was reported for fragments of both genes (VALARCHER; SCHELCHER; BOURHY, 2000).

The characterization of BRSV strains with anti $\mathrm{F}$ and $\mathrm{G}$ protein monoclonal antibodies and phylogenetic analyses based on nucleotide sequences of its coding genes have shown the presence of three distinct antigenic subgroups, named as A, AB (or intermediate), and B. The unclassified isolates were denominated as untyped (FURZE et al., 1994; VAN DER POEL et al., 1994; SCHRIJVER et al., 1996a; WOELK; HOLMES, 2001). The importance of this diversity regarding immunoprophylaxis is not yet completely understood, since it is not known whether vaccination against one BRSV subgroup induces cross-protection, as the natural infection (VAN DER POEL et al., 1994; SCHRIJVER et al., 1996b).

BRSV phylogenetic analyses showed that its distribution may be related to geographic and temporal events (YAEGASHI et al., 2005; VALARCHER; SCHELCHER; BOURHY, 2000; SPILKI et al., 2006). The subgroup A and AB were found in European countries, United States and Japan (FURZE et al., 1994; STINE; HOPPE; CLAYTON, 1997; LARSEN; TJORNEHOJ; VIUFF, 2000; NETTLETON et al., 2003; YAEGASHI et al., 2005) while the subgroup B was isolated in United Kingdom in the 1970s and later was rediscovered in Brazil (NETTLETON et al., 2003; ALMEIDA et al., 2006; VALARCHER; TAYLOR, 2007). All the known Brazilian isolates are classified in this subgroup (ARNS et al., 2003; ALMEIDA et al., 2006; SPILKI et al., 2006; SPILKI; ARNS, 2008; DOMINGUES; SPILKI; ARNS, 2011). Even though, the occurrence of other subgroups in Brazil may not be disregarded, as the number of BRSV 
isolates characterized until now is very small.

In Brazilian herds, BRSV was first detected from lung tissues of slaughtered calves from Southern region (GONÇALVES et al., 1993) and then some serological surveys showed that BRSV infections are spread in animals from Southern and Southeastern regions, reaching high prevalences (CAMPALANS; ARNS, 1997; AFFONSO et al., 2011). Nevertheless, the high serological prevalence compared to low incidence of clinical disease may indicate that most of infections in Brazilian herds are subclinical, hindering control measures for the disease. The present study describes the detection and characterization of an untyped BRSV isolate in Brazil from a herd without history of clinical respiratory disease, using RT-nested PCR and genomic sequencing.

\section{Materials and Methods}

\section{Study area and sampling}

The study was conducted in a dairy farm situated in São Paulo State, Southeastern Brazil. The herd had about 60 crossbred animals and there were no previous reports of clinical respiratory disease in the last six months preceding the collects, despite the high serological prevalence of BRSV, reaching 93.44\%. Vaccination against BRSV was never employed in this farm or in adjacent properties.

Nasal secretions were collected from calves under one year of age using sterile swabs and then stored in DNases- and RNAses-free tubes. Immediately after collection, the samples were transported on ice to the laboratory and stored at $-80^{\circ} \mathrm{C}$, until analyses.

\section{RT-nested PCR and sequencing}

RNAwas extracted from nasal swabs using phenol guanidine isothiocyanate $\left(\mathrm{TRIzol}^{\circledR}\right.$, Invitrogen ${ }^{\mathrm{TM}}$, Carlsbad, CA, USA) and chloroform directly in their storage tubes. After the extraction, cDNA was synthesized with High capacity cDNA Reverse
Transcription kits (Applied Biosystems ${ }^{\circledR}$, Foster City, CA, USA), according to the manufacturer's instructions.

The RT-nested PCR was performed to amplify two fragments with $481 \mathrm{bp}$ and 371 $\mathrm{bp}$, corresponding to part of the BRSV F and $\mathrm{G}$ proteins genes, respectively. The outer and inner primers employed were those described by Vilcek et al. (1994). The PCR 1 final volume of $20 \mu \mathrm{l}$ consisted of $2,0 \mu \mathrm{L}$ of $1 \mathrm{X}$ PCR Buffer, $0,8 \mu \mathrm{L}$ of $\mathrm{MgCl}_{2}(2 \mathrm{mM}), 0,4 \mu \mathrm{L}$ of dNTP mix $(0,2 \mathrm{mM}$ each), $0,2 \mu \mathrm{L}$ of $1,0 \mathrm{U}$ of the enzyme Platinum ${ }^{\circledR}$ Taq DNA polimerase (Invitrogen ${ }^{\mathrm{TM}}$, Carlsbad, CA, USA), 0,4 $\mu \mathrm{L}$ of 1.5 pmol of outer primers B1/B2A (F gene) and B5A/B6 (G gene), 2,0 $\mu \mathrm{L}$ of cDNA and water to complete the final volume. The amplification occurred in a thermocycler Veriti ${ }^{\circledR}$ Thermal Cycler (Applied Biosystems ${ }^{\circledR}$, Foster City, CA, USA) programmed for denaturation at $95^{\circ} \mathrm{C}$ for $4 \mathrm{~min}, 25$ cycles consisting of denaturation at $95^{\circ} \mathrm{C}$ for $1 \mathrm{~min}$, annealing at $53^{\circ} \mathrm{C}(\mathrm{F}$ gene $)$ and $60^{\circ} \mathrm{C}(\mathrm{G}$ gene) for 1 min and elongation at $72^{\circ} \mathrm{C}$ for $1 \mathrm{~min}$ and $30 \mathrm{~s}$. To complete, a final elongation step of $7 \mathrm{~min}$ at $72^{\circ} \mathrm{C}$ was employed. The PCR 2 was conducted with the same quantities of reagents of PCR 1, however, replacing the cDNA for $1 \mu \mathrm{L}$ of product from the first PCR and $1 \mu \mathrm{L}(5 \mathrm{pmol})$ of inner primers B3/ $\mathrm{B} 4 \mathrm{~A}$ ( $\mathrm{F}$ gene) and B7A/B8 ( $\mathrm{G}$ gene). The thermal cycle was the same as described previously, but with 35 cycles and annealing temperature at $53^{\circ} \mathrm{C}$ for $\mathrm{F}$ gene and $62^{\circ} \mathrm{C}$ for $\mathrm{G}$ gene. BRSV ATCC VR1485 strain and a mixture of PCR reagents without product were used as positive and negative controls.

Sequencing was performed from amplified products of the first PCR using the primers "forward" and "reverse" separately and the Big Dye ${ }^{\circledR}$ Terminator v3.1 Cycle Sequencing kit (Applied Biosystems $^{\circledR}$, Foster City, CA, USA) according to the manufacturer's protocol. The samples were loaded on an ABI PRISM ${ }^{\circledR} 3100$ Genetic Analyzer (Applied Biosystems ${ }^{\circledR}$, Foster City, CA, USA) sequencer. 
The Bio Edit software, version 7.01 (HALL, 1999) was used to manipulate the nucleotide and amino acid obtained sequences. The sequences alignment was performed using the ClustalW software, version 1.83 (THOMPSON; HIGGINS; GIBSON, 1994). For the dendrogram construction, bootstrapping of 2000 replicates was performed, using the neighbor-joining method and Kimura-2 parameters, with the software MEGA 4.0 (TAMURA et al., 2007). The DNA sequences were compared with other homologous nucleotide sequences obtained from GenBank Database (http:// www.ncbi.nlm.nih.gov/nucleotide/).

\section{Results}

The RT-nested PCR amplified the fragment correspondent to the $\mathrm{F}$ protein gene in one of the samples, whereas no amplification was detected for the $\mathrm{G}$ protein gene from the same sample. Both $\mathrm{F}$ and $G$ genes were amplified for the BRSV ATCC VR-1485 strain (positive control). These results are shown in Figure 1. RT-nested PCR for G protein gene was repeated at least three times using the positive sample, although there was no successful result in $\mathrm{G}$ gene amplification. The BRSV positive sample was detected from a healthy twenty-days-old calf from a herd without history of respiratory disease, despite showing high serological prevalence of BRSV.

Figure 1. Detection of BRSV sample from nasal swab. Amplicons obtained by RT-nested PCR for F protein gene (A) and $\mathrm{G}$ protein gene (B). Lane M, molecular weight marker; lane 1, positive control; lane 2, positive sample (only for F protein gene); lane 3, negative sample; lane 4, negative control.
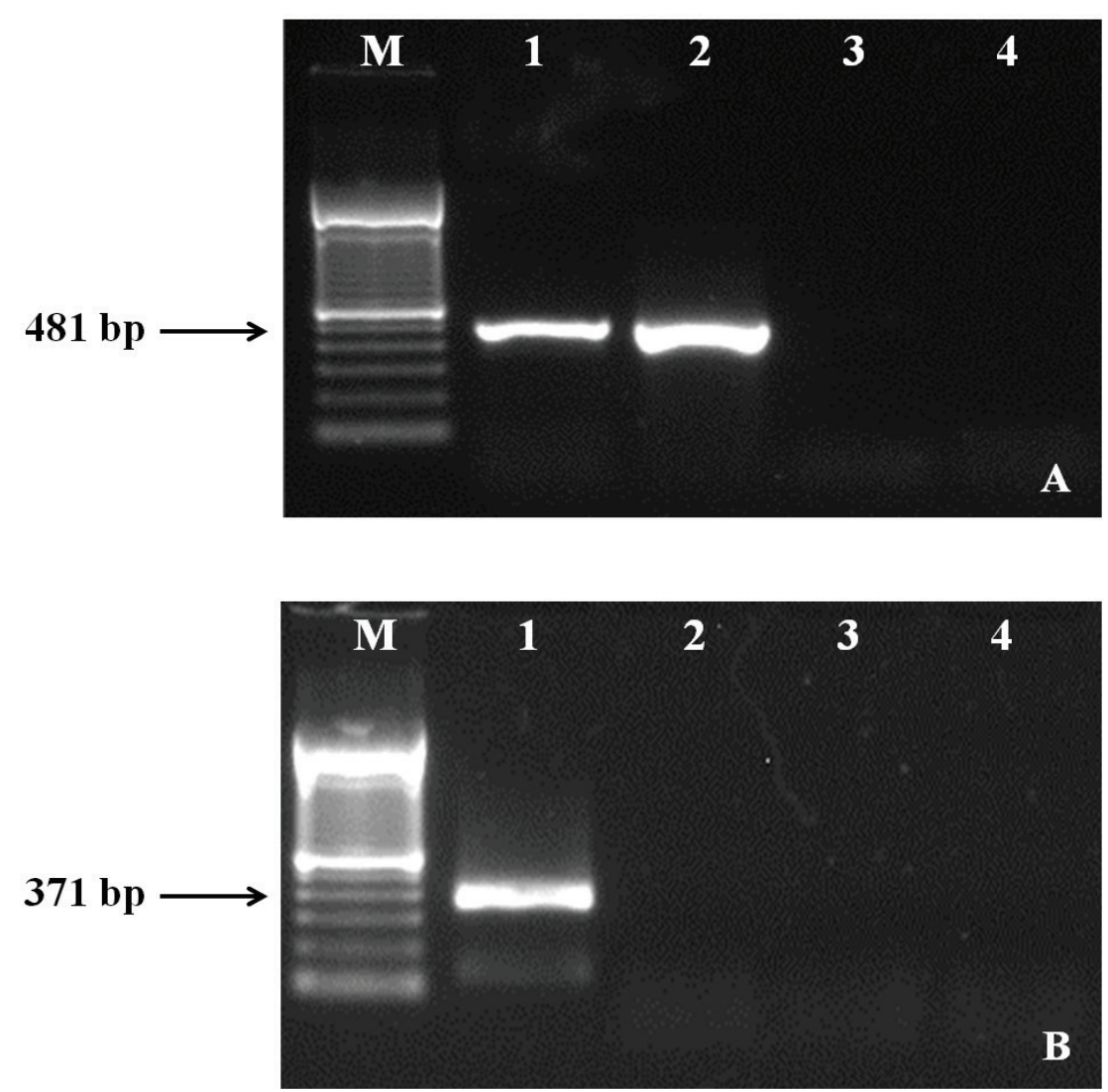

Source: Elaboration of the authors. 
The obtained $\mathrm{F}$ protein gene amplicons for the sample and the positive control were sequenced. The BRSV sample was denominated BRSVUnespJab-1. Phylogenetic relatedness of the BRSV-UnespJab-1 strain with other $\mathrm{F}$ protein gene sequences is shown in Figure 2. In the dendrogram, the BRSV-UnespJab-1 strain did not group with any of BRSV subgroups proposed by Valarcher,
Schelcher and Bourhy (2000), even to subgroup B, in which the BRSV-25-BR isolate, also from Brazil, is classified (ARNS et al., 2003). Therefore, the strain was classified as untyped. The F gene sequence of BRSV ATCC VR-1485 strain was not available in the GenBank Database, however, the sequencing allowed us to characterize it in the subgroup B, along with other reference strain (A51908) and the Brazilian isolate (BRSV-BR-25).

Figure 2. Dendrogram prepared with the F protein gene sequences representing the relatedness of the BRSVUnespJab-1 strain and 28 strains worldwide distributed of BRSV. The method neighbor-joining and Kimura-2 parameter was used and only the bootstrap values higher than $50 \%$ are shown in the phylogenetic reconstruction. GenBank accession numbers are given in each taxon and the correspondent name of the strain is shown in brackets. The BRSV-UnespJab-1 is indicated with a triangle; ovine respiratory syncytial virus (ORSV) and HRSV sequences were utilized as outgroups.

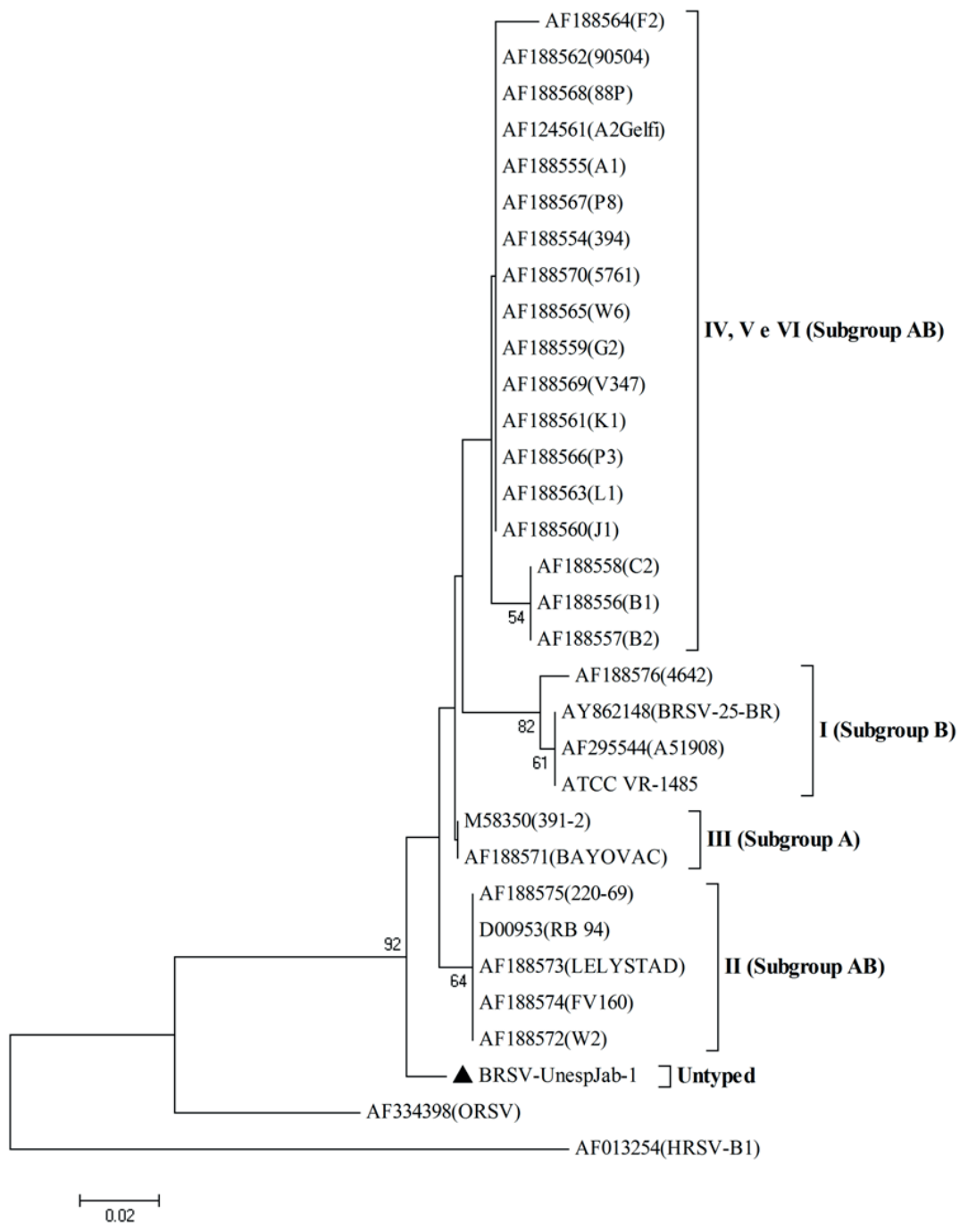

Source: Elaboration of the authors. 
Although the BRSV-UnespJab-1 strain could not be grouped with any of the subgroups, its nucleotide sequence compared to representative strains of BRSV from subgroup AB (RB94), A (391-2) and B (BRSV-25-BR) was not very different (Figure 3 ) showing the possibility of a small accumulation of mutations. These mutations may have been synonymous, once the amino acid sequence was also not significantly altered.
Therefore, the fragment KKRKRRFL which originates the fusion peptide, responsible for the protein penetration in host cells, is well conserved (Figure 4). The nucleotide and amino acid degrees of homology with the subgroups was higher than $92 \%$, and the strain was closest to the subgroup A, with nucleotide and amino acid homology percentages to $96 \%$ and $97.7 \%$, respectively (Table 1).

Table 1. Homology percentages of $\mathrm{F}$ protein nucleotide and amino acid sequences among the BRSV-UnespJab-1 strain and representatives BRSV subgroups.

\begin{tabular}{lcccc}
\hline & RB94 (AB) & $391-2(\mathrm{~A})$ & BRSV-25-BR (B) & BRSV-UnespJab-1 \\
\hline RB94 (AB) & - & 95,4 & 96,2 & 93,2 \\
391-2 (A) & 95,7 & - & 94,7 & 97,7 \\
BRSV-25-BR (B) & 96,7 & 94 & - & 92,4 \\
BRSV-UnespJab-1 & 95,2 & 96 & 93,5 & - \\
\hline
\end{tabular}

Nucleotide and amino acid values of identity are given in normal and italic letters, respectively.

Source: Elaboration of the authors.

\section{Discussion}

Despite the high BRSV serological prevalence found in the studied herd, this fact did not indicate the possibility of BRSV molecular detection. However, as calves are more susceptible to BRSV infection, the chances of elimination and detection the virus is higher in these animals. Other researchers also detected the virus in cattle without clinical signs of respiratory disease in Brazil (DOMINGUES; SPILKI; ARNS, 2011). Thus, the BRSV occurrence in herds with no report of clinical disease seems to be very common and may be an important mechanism for maintenance of the virus in the country.

The BRSV positive sample amplified only for the $\mathrm{F}$ protein gene, even though the positive control BRSV ATCC VR-1485 strain amplified both F and $\mathrm{G}$ genes. Other authors using the same primers obtained G protein gene amplicons (VILCEK et al., 1994; ALMEIDA et al., 2005; BIDOKHTI et al., 2012). The accuracy of the RT-nested PCR for $\mathrm{G}$ gene was confirmed by the repetition of the technique at least three times, with some changes in the protocol, like the annealing temperature, although any amplicon was obtained.

Since the sequencing of the $\mathrm{F}$ protein gene reaffirmed that the positive sample is indeed a BRSV strain, it may suggest that the G gene was not detected by the employed primers due to a possible accumulation of mutations in this gene. This fact may be affirmed by studies showing high variation in G protein gene (VALARCHER; SCHELCHER; BOURHY, 2000; BIDOKHTI et al., 2012). In Brazil, Spilki et al. (2006) also reported significant differences in amino acid composition of the $G$ protein gene from the BRSV-25-BR isolate when compared to others; however, this isolate grouped within the subgroup B. Despite these hypotheses, the fact that the BRSV-UnespJab-1 strain did not amplify for the $\mathrm{G}$ protein gene remains unknown. 
Figure 3. F protein gene nucleotide sequences (positions 204-600) of BRSV-UnespJab-1, BRSV ATCC VR-1485 strain and representatives isolates from subgroup A (391-2), AB (RB94) and B (BRSV-25-BR).

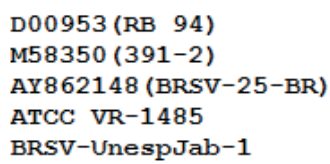

Source: Elaboration of the authors.

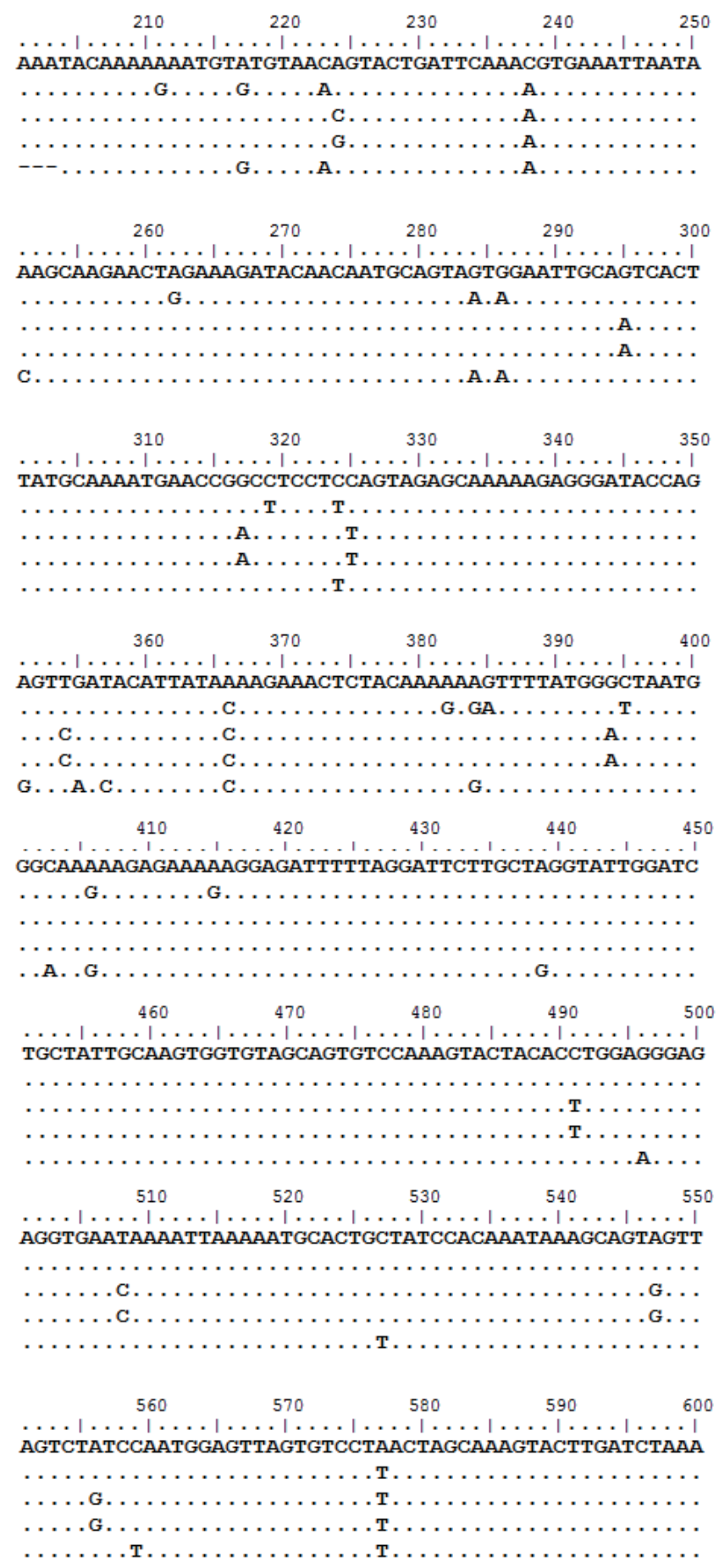



50 
Figure 4. Alignment of the amino acid residues (region 61-200) which comprises the fusion peptide (KKRKRRFL) showing the differences among BRSV-UnespJab-1 and isolates from subgroup A (391-2), AB (RB94) and B (BRSV25-BR).

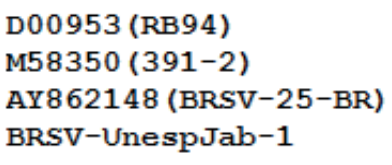

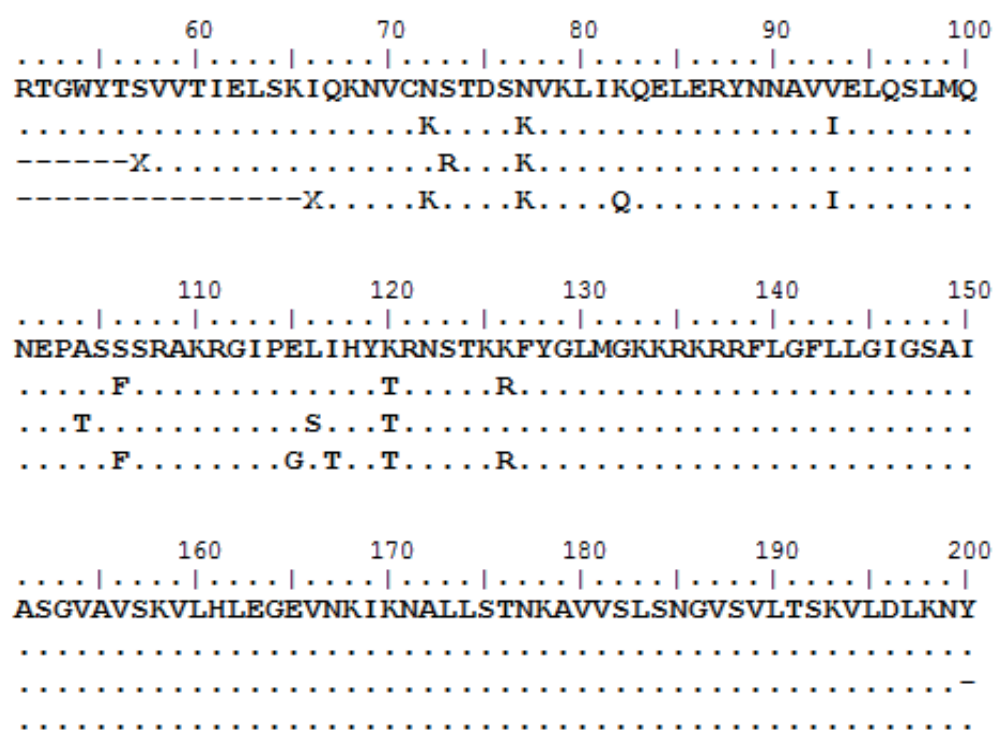

Source: Elaboration of the authors.

The BRSV-UnespJab-1 sequencing and its phylogenetic relatedness with other sequences from the GenBank revealed that the strain does not belong to any of the previously described BRSV subgroups, although it showed slightly higher nucleotide and amino acid identities with subgroup A strains (Table 1). In Brazil, a phylogenetic tree was made for the $\mathrm{F}$ protein gene and showed that only isolates of the subgroup B were found until now (SPILKI; ARNS, 2008). However, as a limited number of strains were characterized, other BRSV subgroups may be present in Brazilian herds.

The BRSV $\mathrm{F}$ protein is considered more conserved than the $\mathrm{G}$, but both genes are in constant changing. Valarcher, Schelcher and Bourhy (2000) verified important rates of nucleotide changes per synonymous and nonsynonymous sites for the BRSV proteins genes, however, the synonymous nucleotide changes for the $\mathrm{F}$ protein gene were higher than nonsynonymous. This fact may explain the small nucleotide and amino acid changes found in BRSV-UnespJab-1, in which the fusion peptide remained preserved. Thus, despite being a distinct strain, the F protein function may have kept unchanged.

The BRSV characterization, either using monoclonal antibodies or sequencing, do not always permit to classify the isolates according to the subgroups described in the literature, showing many untyped strains (FURZE et al., 1994, FURZE et al., 1997; SCHRIJVER et al., 1996a; SCHRIJVER et al., 1998). However, it is not available an untyped BRSV $F$ protein gene sequence in GenBank to compare with the BRSV-UnespJab-1. The better characterized untyped isolate of BRSV, namely the Dutch strain WBH, has only available the G protein gene sequence, thus avoiding the comparison with BRSV-UnespJab-1.

In the evolutionary analyses of European isolates, Valarcher, Schelcher and Bourhy (2000) found that BSRV combines high rates of sequence evolution and amino acid changes in antigenically important regions of the $\mathrm{G}$ protein gene, and these changes provide the opportunity to the virus escape from the host immune system. Thus, changes 
in these regions may have been exacerbated by the extensive use of vaccines against BRSV in European cattle herds, since the vaccine might have promoted a selective pressure on the virus in these herds. Differently, the vaccination against BRSV is rarely performed in Brazil and then the differences found in Brazilian strains may be related to geographic isolation provided by decrease of cattle imports from Europe and also by the selection of virus escape mutants in BRSV reinfections.

The characterization of an untyped BRSV strain in Brazil demonstrates that the virus is in constantly evolution in nature and question whether the use of vaccines as a control method in the country is relevant, since it is not known the degree of protection among the BRSV subgroups. Thus, in a country with large cattle production and with great territorial extension like Brazil, more detailed studies concerning the BRSV characterization would be essential to recommend the use of appropriate vaccines to the virus strain present in a given region.

\section{Acknowledgments}

This work was supported by Fundação de Amparo à Pesquisa do Estado de São Paulo - FAPESP (financial grant 2010/15912-7 and doctoral scholarship 2010/06950-2). The authors thank Dr. Antonio Nader Filho, Dr. Eliana G. de Macedo Lemos for laboratorial support and Dr. Estevam G. Lux Hoppe for assistance with manuscript redaction.

\section{References}

AFFONSO, I. B.; GATTI, S. P.; ALEXANDRINO, B.; OLIVEIRA, M. C.; MEDEIROS, A. S. R.; BUZINARO, M. G.; SAMARA, S. I. Detection of antibodies against bovine respiratory syncytial virus (BRSV) in dairy cattle with different prevalences of bovine herpesvirus type 1 (BHV-1) in São Paulo State, Brazil. Semina: Ciências Agrárias, Londrina, v. 32, n. 1, p. 295-300, 2011.
ALMEIDA, R. S.; DOMINGUES, H. G.; SPILKI, F. R.; LARSEN, L. E.; HAGGLUND, S.; BELÁK, S.; ARNS, C. W. Circulation of bovine respiratory syncytial virus in Brazil. Veterinary Record, London, v. 158, n. 18, p. 632-634, 2006.

ALMEIDA, R. S.; SPILKI, F. R.; ROEHE, P. M.; ARNS, C. W. Detection of Brazilian bovine respiratory syncytial virus strain by a reverse transcriptase-nestedpolymerase chain reaction in experimentally infected calves. Veterinary Microbiology, Amsterdam, v. 105, n. 2, p. 131-135, 2005.

ARNS, C. W.; CAMPALANS, J.; COSTA, S. C. B.; DOMINGUES, H. G.; D’ARCE, R. C. F.; ALMEIDA, R. S. Characterization of bovine respiratory syncytial virus isolated in Brazil. Brazilian Journal of Medical and Biological Research, Ribeirão Preto, v. 36, n. 2, p. 213218, 2003.

BAKER, J. C.; FREY, M. Bovine respiratory syncytial virus. Veterinary Clinics of North America: Food Animal Practice, Philadelphia, v. 1, n. 2, p. 259-272, 1985.

BIDOKHTI, M. R. M.; TRAVÉN, M.; OHLSON, A.; ZARNEGAR, B.; BAULE, C.; BELÁK, S.; ALENIUS, S.; LIU, L. Phylogenetic analysis of bovine respiratory syncytial viruses from recent outbreaks in feedlot and dairy cattle herds. Archives of Virology, New York, v. 157, n. 4, p. 601-607, 2012.

BUNT, A. A.; MILNE, R. G.; SAYAYA, T.; VERBEEK, M.; VETTEN, H. J.; WALSH, J. A. Paramyxoviridae. In: FAUQUET, C. M.; MAYO, M. A.; MANILOFF, J.; DESSELBERGER, U.; BALL, L. A. (Ed.). Virus taxonomy, eigth report of the international committee on taxonomy of viruses. London: Elsevier: Academic Press, 2005. p. 655-671.

CAMPALANS, J.; ARNS, C. W. Serological evidence of bovine respiratory syncytial virus in Brazil. Virus Reviews and Research, Belo Horizonte, v. 2, n. 1-2, p. 50-56, 1997.

DOMINGUES, H. G.; SPILKI, F. R.; ARNS, C. W. Detecção molecular e análise filogenética de vírus respiratório sincicial bovino (BRSV) em swabs e tecido pulmonar de bovinos adultos. Pesquisa Veterinária Brasileira, Rio de Janeiro, v. 31, n. 11, p. 961-966, 2011.

FURZE, J. M.; ROBERTS, S. R.; WERTZ, G. W.; TAYLOR, G. Antigenically distinct $G$ glycoproteins of BRSV strains share a high degree of genetic homogeneity. Virology, New York, v. 231, n. 1, p. 48-58, 1997.

FURZE, J.; WERTZ, G.; LERCH, R.; TAYLOR, G. Antigenic heterogeneity of the attachment protein of bovine respiratory syncytial virus. Journal of General Virology, London, v. 75, n. 2, p. 363-370, 1994. 
GONÇALVES, I. P. D.; SIMANKE, A. T.; JOST, H. C.; HÖTZEL, I.; DAL SOGLIO, A.; MOOJEN, V. Detection of bovine respiratory syncytial virus in calves of Rio Grande do Sul, Brazil. Ciência Rural, Santa Maria, v. 23, n. 3, p. 389-390, 1993.

HALL, T. A. BioEdit: a user-friendly biological sequence alignment editor and analysis program for Windows 95/98/NT. Nucleic Acids Symposium Series, Oxford, n. 41, p. 95-98, 1999.

LARSEN, L. E. Bovine respiratory syncytial virus (BRSV): a review. Acta Veterinaria Scandinavica, Copenhagen, v. 41, n. 1, p. 1-24, 2000.

LARSEN, L. E.; TJORNEHOJ, K.; VIUFF, B. Extensive sequence divergence among bovine respiratory syncytial viruses isolated during recurrent outbreaks in closed herds. Journal of Clinical Microbiology, Washington, v. 38, n. 11, p. 4222-4227, 2000.

NETTLETON, P. F.; GILRAY, J. A.; CALDOW, G.; GIDLOW, J. R.; DURKOVIC, B.; VILCEK, S. Recent isolates of Bovine respiratory syncytial virus from Britain are more closely related to isolates from USA than to earlier British and current mainland European isolates. Journal of Veterinary Medicine Series B-Infectious Diseases and Veterinary Public Health, Berlin, v. 50, n. 4, p. 196-199, 2003.

PROZZI, D.; WALRAVENS, K.; LANGEDIJK, J. P.; DAUS, F.; KRAMPS, J. A.; LETESSON, J. J. Antigenic and molecular analyses of the variability of bovine respiratory syncytial virus G glycoprotein. Journal of General Virology, London, v. 78, n. 2, p. 359-366, 1997.

SCHRIJVER, R. S.; DAUS, F.; KRAMPS, J. A.; LANGEDIJK, J. P. M.; BUIJS, R.; MIDDEL, W. G. J.; TAYLOR, G.; FURZE, J.; HUYBEN, M. W. C.; VAN OIRSCHOT, J. T. Subgrouping of bovine respiratory syncytial virus strains detected in lung tissue. Veterinary Microbiology, Amsterdam, v. 53, n. 3-4, p. 253-260, 1996a.

SCHRIJVER, R. S.; LANGEDIJK, J. P. M.; VAN DER POEL, W. H. M.; MIDDEL, W. G. J.; KRAMPS, J. A.; VAN OIRSCHOT, J. T. Antibody responses against the $\mathrm{G}$ and $\mathrm{F}$ proteins of bovine respiratory syncytial virus after experimental and natural infections. Clinical and Diagnostic Laboratory Immunology, Washington, v. $3, \mathrm{n}$. 5, p. 500-506, 1996b.

SCHRIJVER, R. S.; LANGEDIJK, J. P. M.; MIDDEL, W. G. J.; KRAMPS, J. A.; RIJSEWIJK, F. A. M.; VAN OIRSCHOT, J. T. A bovine respiratory syncytial virus strain with mutations in subgroup-specific antigenic domains of the $\mathrm{G}$ protein induces partial heterologous protection in cattle. Veterinary Microbiology, Amsterdam, v. 63, n. 2-4, p. 159-175, 1998.
SPILKI, F. R.; ALMEIDA, R. S.; DOMINGUES, H. G.; D'ARCE, R. C. F.; FERREIRA, H. L.; CAMPALANS, J.; COSTA, S. C. B.; ARNS, C. W. Phylogenetic relationships of Brazilian bovine respiratory syncyctial virus isolates and molecular homology modeling of attachment glycoprotein. Virus Research, Amsterdam, v. 116, n. 1-2, p. 161-168, 2006.

SPILKI, F. R.; ARNS, C. W. Vírus respiratório sincicial bovino. Acta Scientiae Veterinariae, Porto Alegre, v. 36, n. 3, p. 197-214, 2008.

STINE, L. C.; HOPPE, D. K.; ClAYTON, L. K. Sequence conservation in attachment glycoproteins and antigenic diversity among bovine respiratory syncytial virus isolates. Veterinary Microbiology, Amsterdam, v. 54, n. 3-4, p. 201-221, 1997.

TAMURA, K.; DUDLEY, J.; NEI, M.; KUMAR, S. MEGA 4: molecular evolutionary genetics analysis (MEGA) software version 4.0. Molecular Biology and Evolution, Chicago, v. 24, n. 8, p. 1596-1599, 2007.

TAYLOR, G.; STOTT, E. J.; FURZE, J.; FORD, J.; SOPP, P. Protective epitopes on the fusion protein of respiratory syncytial virus recognized by murine and bovine monoclonal antibodies. Journal of General Virology, London, v. 73, n. 9, p. 2217-2223, 1992.

TAYLOR, G.; THOMAS, L. H.; FURZE, J. M.; COOK, R. S.; WYLD, S. G.; LERCH, R.; HARDY, R.; WERTZ, G. W. Recombinant vaccinia viruses expressing the $\mathrm{F}$, $\mathrm{G}$ or $\mathrm{N}$, but not the M2, protein of bovine respiratory syncytial virus (BRSV) induce resistance to BRSV challenge in the calf and protect against the development of pneumonic lesions. Journal of General Virology, London, v. 78, n. 12, p. 3195-3206, 1997.

THOMAS, L. H.; COOK, R. S.; WYLD, S. G.; FURZE, J. M.; TAYLOR, G. Passive protection of gnotobiotic calves using monoclonal antibodies directed at different epitopes on the fusion protein of bovine respiratory syncytial virus. Journal of Infectious Diseases, Chicago, v. 177, n. 4, p. 874-880, 1998.

THOMPSON, J. D.; HIGGINS, D. G.; GIBSON, T. J. Clustal W: improving the sensitivity of progressive multiple sequence alignment through sequence weighting, positions-specific gag penalties and weight matrix choice. Nucleic Acids Research, Oxford, v. 22, n. 22, p. 4673-4680, 1994.

VALARCHER, J. F.; SCHELCHER, F.; BOURHY, H. Evolution of bovine respiratory syncytial virus. Journal of Virology, Washington, v. 74, n. 22, p. 10714-10728, 2000.

VALARCHER, J. F.; TAYLOR, G. Bovine respiratory syncytial virus infection. Veterinary Research, Les Ulis, v. 38, n. 2 , p. $153-180,2007$. 
VAN DER POEL, W. H.; BRAND, A.; KRAMPS, J. A.; VAN OIRSCHOT, J. T. Respiratory syncytial virus infections in human beings and in cattle. Journal of Infectious Diseases, Chicago, v. 29, n. 2, p. 215-228, 1994.

VILCEK, S.; ELVANDER, M.; BALLAGI-PORDÁNY, A.; BELÁK, S. Development of nested PCR assays for detection of bovine respiratory syncytial virus in clinical samples. Journal of Clinical Microbiology, Washington, v. 32, n. 9, p. 2225-2231, 1994.
WOELK, C. H.; HOLMES, E. C. Variable immune-driven natural selection in the attachment $(\mathrm{G})$ glycoprotein of respiratory syncytial virus (RSV). Journal of Molecular Evolution, Chicago, v. 52, n. 2, p. 182-192, 2001.

YAEGASHI, G.; SEIMIYA, Y. M.; SEKI, Y.; TSUNEMITSU, H. Genetic and antigenic analyses of bovine respiratory syncytial virus detected in Japan. Journal of Veterinary Medical Science, Tokyo, v. 67, n. 2, p. 145-150, 2005. 
